Review

\title{
Islet Identity in Transplantation Procedures: The Intersection of Cellular Maturity and Function
}

Christine A. Beamish ${ }^{1}$, Omaima M. Sabek ${ }^{1,2, *}$

1. Department of Surgery, Houston Methodist Hospital, Houston TX, USA; E-Mails: cbeamish@houstonmethodist.org; OMSabek@houstonmethodist.org

2. Department of Cell and Microbiology Biology, Weill Cornell Medical College, NY, USA.

* Correspondence: Omaima M. Sabek; E-Mail: OMSabek@houstonmethodist.org

Academic Editor: Kåre I. Birkeland

Special Issue: Current Advancement of Islet Cell Transplantation in the Treatment of Diabetes Mellitus

OBM Transplantation

2019, volume 3 , issue 1

doi:10.21926/obm.transplant.1901055
Received: November 08, 2018

Accepted: February 10, 2019

Published: March 05, 2019

\begin{abstract}
Pancreatic islet transplantation holds promise for patients with insulin-dependent diabetes, but is severely limited by a shortage of cadaveric donor islets, and more so because of stringent inclusion criteria for organ donation including donor metabolic function, age, and comorbidities. The impact of these diverse factors on islet health has led to a broad investigation of global influences on islet biology, not least of all, characterization of mature, functional cellular identity and maintenance of appropriate endocrine lineage. This review will present the current knowledge on $\beta$-cell heterogeneity and inherent plasticity, and the role of cellular dedifferentiation of islets and $\beta$-cells in the normal and pathophysiological states, including aging, diabetes subtypes, and islet transplantation. Examination of potential strategies for reduction of metabolic stress by endogenous and exogenous modes is further discussed.
\end{abstract}

\section{Keywords}

Dedifferentiation; islet; transplantation; metabolic syndrome; diabetes; cellular identity; beta-cell heterogeneity

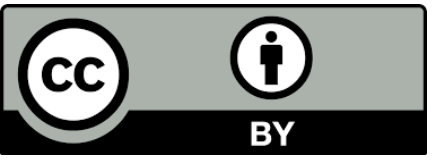

(C) 2019 by the author. This is an open access article distributed under the conditions of the Creative Commons by Attribution License, which permits unrestricted use, distribution, and reproduction in any medium or format, provided the original work is correctly cited. 


\section{Summary}

Over the past two decades, the Edmonton Protocol made islet allotransplantation a feasible clinical procedure which has resulted in over 1500 patients being transplanted in international centers [1, 2]. Islet transplantation is an effective and relatively noninvasive procedure for restoring endogenous insulin production and protecting against both severe hypoglycemia and microvascular complications [3-7], thus improving glycemic control and quality of life even in those grafts which retain only partial function [8, 9]. In recent years, advances in islet transplantation procedures such as standardization of islet processing, engraftment, immunosuppression/immunomodulation regimens, and identification of dynamic islet donor factors has resulted in improved clinical outcomes [10-13]. However, due to sustained cadaveric islet shortages and immunosuppression requirements, the majority of patients are not currently eligible for transplantation, restricting this technique only to those with hypoglycemia unawareness and/or end-stage renal disease [14, 15]; moreover, those patients who do meet inclusion criteria still require 2-3 repeated transplants to achieve insulin independence, severely limiting the number of benefitting recipients. Thus, implementation of islet transplantation to treat more patients requires a deeper understanding of donor factors such as islet- and $\beta$-cell heterogeneity, and the relationship between $\beta$-cell identity and function.

\section{Beta-Cell Heterogeneity: Development, Aging, and Inherent Plasticity}

Pancreatic $\beta$-cell identity has been shown to be a surprisingly fluid state, changing with age, development, and disease. Although not a new concept, cellular differentiation from the mature state has gained traction as a physiological response to stress or external stimuli, in an attempt to effect the cell's survival or to re-establish homeostasis. Loss of cell identity can be defined in two broad ways: dedifferentiation, the loss of defining, functional, and/or mature cellular characteristics from a terminally differentiated cell type [16, 17]; and transdifferentiation, the change from one mature cell type to another, which can take the route of a direct transition, or alternatively, to utilize an intermediate state [16]. Transition between "mature" to "dedifferentiated" states has been shown to result from opposing influences of contextdependent stress evasion/survival and regeneration forces. Importantly, the ability to direct this process is of critical importance for the treatment of diabetes.

While generation of functional $\beta$-cell mass from non- $\beta$-cell-source is of critical interest and hope for diabetes therapy, this review will focus on $\beta$-cell heterogeneity in vivo specifically; in the least, utilization of induced pluripotent stem cells (iPSc) and human embryonic stem cell (HESc) source for organ renewal is both optimistic and provocative in its scope. Elegant reviews of the endocrine pancreas developmental program [18, 19], and novel protocols for the attempt at recapitulation and exploitation of these processes in vitro and in vivo [20-28] for functional islet mass generation provide a framework for the current examination of islet cell identity in the transplantation milieu.

Insulin hormone presence is the standard-bearer for $\beta$-cell identity, however other components must be present and functional, which include glucose sensing, cell excitability, insulin processing 
and secretion, and the presence of specific transcription factors (TFs) which control the transcriptional programs that provide for the other endocrine functional traits listed [29]. Under normal circumstances, $\beta$-cell replication in the mature mammalian pancreas is extremely low [30, 31], although compensatory increases in proliferation have been documented, such as obesity, high-fat diets, injury models, and pregnancy [32-35]. Evidence for the loss of $\beta$-cell proliferative capacity linked to aging and T2D have been proposed [36-38], and may be mediated by p16 ink4a [39]. Indeed, $\beta$-cell proliferation has been shown to be a state of phenotypic immaturity, necessary for cellular growth and modulated by the master regulator gene c-Myc [40]. Others have further suggested that transient $\beta$-cell dedifferentiation during proliferation involves a transition to a PP-positive cell state, and under the control of Smad7 [41].

Multiple examples of in vivo $\beta$-cell lineage plasticity have been described. In both mice and human pancreas, a subpopulation of rare lineage-plastic $\beta$-cells was identified, generating progeny with non- $\beta(\alpha, \delta, \gamma)$, pancreatic ductal, and even neural cell fates [42-44]. These cells were broadly classified by their increased proliferative capacity, and a lack of functional and maturation markers, including the glucose transporter-2 Glut2 (SLC2A2) [42, 45]. Intriguingly, these cells maintain insulin expression, albeit in lower levels than in fully functional endocrine cells [42]. In the early postnatal mouse and human pancreas, these cells were found in higher proportion in the small, extra-islet clusters of $\beta$-cells than in prototypical islets [43]; as the endocrine pancreas remodels with age, these cells decrease in proportion [46], paralleling the decrease in $\beta$-cell proliferative capacity and the simultaneous increase in functional glucose responsiveness. Importantly, these cells proliferate during times of increased metabolic demand, such as diabetes [47] and following exposure to the specific $\beta$-cell toxin, streptozotocin [48], thus attempting to replenish functional $\beta$ cell mass and maintenance of glucose homeostasis. Moreover, these cells show a robust proportional increase in the pregnant female mouse -- a classic model of rare postnatal $\beta$-cell proliferation -- immediately preceding the increase in $\beta$-cell mass required for fetal somatic growth and in response to hormonal influence [48]. These Ins ${ }^{+} \mathrm{Glut} 2^{\mathrm{LO}}$ cells subsequently decrease shortly before parturition, allowing appropriate endocrine pancreas remodeling in the perigestational and postpartum period [49].

The genetic signature of fate-undefined $\beta$-cells has been rigorously examined; in addition to low insulin and a relative lack of Glut2, these Ins $^{+}$Glut $2{ }^{\mathrm{LO}}$ cells demonstrate alterations in the relative expression levels of MafB, Pdx1, Nkx6.1, and Ngn3 [42, 43], suggesting an immature $\beta$-cell phenotype in vivo. Others have similarly showed a population of $\mathrm{Pd} \times 1^{+}$Ins ${ }^{\text {low }} \beta$-cells which demonstrates low expression of Glut2, Gck, and MafA, whilst being proliferative [50]. In yet another example, a collection of insulin-lineage reporter-labelled $\beta$-cells was found to demonstrate an immature phenotype, with increased expression of $\mathrm{Pdx} 1$ and MafB, and a lack of Nkx6.1 and Glut2 [51]. In these and other examples, the cells of interest participated in a renewal of $\beta$-cell mass during aging and after injury [50-52].

This immature $\beta$-cell phenotypic signature has been further reinforced, such as the lack of the $\beta$-cell maturation marker Urocortin 3 (Ucn3) [53, 54]. The spatial orientation of these Ucn3deficient $\beta$-cells was suggested to be at the islet periphery, in what the authors' term a "neogenic niche" for "virgin" $\beta$-cells [55]. These cells were proposed to be the result of early transdifferentiation from $\alpha$-cells, representing an early intermediate stage of development, but which persist throughout life, decreasing in proportion with age [55]. Bader and colleagues have shown that Flattop (Fltp), a planar-cell polarity gene responsible for maintenance of the rosette 
structure of cells within the pancreas can be used to distinguish mature from proliferative $\beta$-cells [56]. The Fltp-negative, proliferative $\beta$-cells contained less Glut2, Ucn3, MafA, and Nkx6.1, which echoed findings from others $[42,43,53,57]$. In another study, Johnston et al reported that $\beta$-cell "hubs" exist, intermingled amongst other $\beta$-cells within the islet; analogous to a pacemaker, these specialized $\beta$-cells dictate responses to glucose [58]. These hub $\beta$-cells represent less than $10 \%$ of cells by total number, demonstrate a transcriptionally immature phenotype, and are highly metabolically active. And in yet a further example, Westacott and others found that these pacemaker $\beta$-cells control electrical dynamics, thus controlling insulin secretion [59]. These data suggest that islet architecture, including size or number of cells within an islet, location of $\beta$-cells within the islet or pancreas, and planar orientation, has direct impact on islet function. Whether these cells represent a precursor/resident stem cell population, or simply a population of $\beta$-cells which can be recruited in times of increased metabolic demand, may be a qualified argument, as many of the same markers define early and late (or, alternatively, mature and immature) $\beta$-cells, albeit in varying amounts. However, their utility in tissue repair remains steadfast, and further information is required to identify, and/or protect them clinically, particularly when making islet transplantation decisions. This further provides enhanced rationale for protecting existing cell populations, as these data deliver convincing evidence that islet cells do not exclusively die during disease progression, as was the canonical assumption; instead, a population of them survive, but cease to behave as functional endocrine cells.

These data also show the prevalence and breadth of $\beta$-cell heterogeneity. Beta-cell phenotypic non-conformity was quantified by mass cytometry in isolated human islets using surface markers for various hormones and proliferation. Provocative results from "barcoding" cell populations suggest that $\beta$-cells exist within many cell states, specifically within those proliferating endocrine cells [60]. Three major clusters of $\beta$-cells within individuals were reported, correlating roughly with proliferation and age metrics [60]. A similar study found that $\beta$-cells occupied one of four states when assessed by the differential expression of ST8SIA1 and CD9 [61]. The majority of $\beta$-cells were absent for both ST8SIA1 and CD9 in healthy donors; in contrast, ST8SIA1 presence was markedly increased in islets from donors with T2DM. The ST8SIA1-positive $\beta$-cells were less glucose responsive, suggesting functional and clinical deficits [61]. In yet another study, isolated single $\beta$ cells were shown to exist within at least 2 states by software analysis of $\mathrm{Ca}^{2+}$ responses to high glucose [62]. Unsurprisingly, there is also evidence for sex differences underlying $\beta$-cell function and pathology [63], including GSIS assessments and DNA methylation patterns [64]. Importantly, these changes are not only found to be variable between pancreata of different donors, but also within the pancreas of the same donor, layering complexity onto our understanding of islet biology.

\section{The Genetic Makeup of $\beta$-Cells Defines Their Function}

The presence or absence of specific genes, transcription factors, and proteins has been proposed to maintain or change $\beta$-cell fate. Puri et al showed that deletion of the von HippelLindau $(V h l)$ gene, which regulates the hypoxic response via the transcription factor hypoxiainducible factor (HIF), causes negative effects to $\beta$-cell gene expression. They and others have found a relationship between the HIF-hypoxia response pathway and glucose homeostasis: the loss of $\mathrm{Vhl}$ effected a phenotype similar to diabetes and caused alterations to endocrine identity 
$[65,66]$. The authors attributed this change to the inappropriate maintenance of Sox9, present in $\beta$-cell progenitors but normally excluded from mature $\beta$-cells. Thus, under hypoxic conditions, the $\beta$-cell dedifferentiates in order to survive.

$\mathrm{Nkx2.2}$ is expressed in the developing pancreas and later restricted to the endocrine-lineage, including $\alpha, \beta, P P$, and $\varepsilon$-cells [67]. In the adult, Nkx2.2 is maintained in $\alpha, \beta$, and PP-cells. Genetic deletion of $\mathrm{Nkx2.2}$ was shown to decrease generation of $\alpha$ and PP cells, and halt $\beta$-cell specification, causing lethal hyperglycemia. These lineage-unspecified cells produced none of the four endocrine hormones, but did express some $\beta$-cell markers including Pdx1 and IAPP, the protein component of islet amyloid, islet amyloid polypeptide (IAPP, or amylin), yet lacked Glut2 and Nkx6.1 [68]. Nkx2.2 is part of a large repression complex in $\beta$-cells that includes DNMT3a, Grg3, and HDAC1, and prevents $\beta$ - to $\alpha$ - cell reprogramming [69]. Guttierez et al recently demonstrated that deletion of $\mathrm{Nkx2.2}$ in mature mouse $\beta$-cells caused rapid onset of hyperglycemia, loss of insulin production, and down-regulation of $\beta$-cell genes. Furthermore, there was evidence of cellular reprogramming and bihormonal cells in the Nkx2.2-null $\beta$-cells that acquired non- $\beta$ cell endocrine features, suggesting that $\beta$-cell identity requires continual repression of non- $\beta$ cell programs [70].

The TF Arx normally specifies $\alpha$-cell fate and simultaneously represses the $\beta$ - and $\delta$ - lineages [71]. In a gain-of-function experiment, forced expression of Arx in the embryonic pancreas or in developing islet cells caused fatally high hyperglycemia in mice. This was a result of near-complete loss of $\beta$ - and $\delta$-cells, and a concurrent increase in the proportion of $\alpha$ - and PP-cells. Intriguingly, the mis-expression of Arx in adult $\beta$-cells in vivo resulted in their conversion to $\alpha$ - and PP-cells [72]. Alpha-to-beta transdifferentiation and $\alpha$-cell identity loss has been effected by targeting Arx, shown in multiple reports [73, 74], and in one report, with concurrent targeting of DNA methyltransferase 1 (Dnmt1) [75]. Interestingly, Wilcox et al reported that the Arx-negative cells which underwent a transdifferentiation via a bihormonal state expressed $\beta$-cell markers including $P d x 1$, MafA, and Glut2 in the neonate, but not adult mouse $\beta$-cells [74]. Li et al reported that artemisinins, antimalarial drugs that repress Arx by causing its translocation to the cytoplasm, could be used as a cell source for $\beta$-cell replacement strategies for T1DM patients. The authors purported that artemisinins, including artemether, increase GABA signaling and prevent glucagon secretion by $\alpha$-cells, resulting in their consequent loss of identity and transdifferentiation to a $\beta$ like phenotype, with associated increased insulin content and improvement in GSIS assessments [76]. However, follow up reports challenged these results, showing that neither artemisinins nor GABA directly cause $\alpha$ - to $\beta$-cell conversion $[77,78]$.

The TF Pax4 has been shown to specify $\beta$-cells from endocrine progenitors [79]. In an experiment of ectopic Pax4 expression in both endocrine progenitor and adult endocrine cells, $\alpha$ cells were re-specified towards a $\beta$-cell phenotype, generating oversized islets [80]. A subsequent model utilizing double-transgenic mice of inducible, ectopic, and reversible expression of Pax4 in glucagon-positive cells showed that adult $\alpha$-cells can be converted to $\beta$-cells [81]. The authors report this to be Ngn3-dependent which redirects precursor cells in the duct to develop as $\beta$-cells via an $\alpha$-cell intermediary state, and capable of $\beta$-cell mass replenishment after targeted depletion [81]. Pax6 is similarly necessary to maintain $\beta$-cell identity, as deletion in the adult causes severe hyperglycemia, reduced GSIS, deficient glucose-sensing, and down-regulation of key $\beta$-cell genes; this deletion also "un-inhibited" selectively repressed genes for the $\beta$-cell program [82]. 
Injury models have demonstrated the attempts of the pancreas to replace lost $\beta$-cell mass, sometimes in unorthodox ways. Alpha cells were shown to transdifferentiate to $\beta$-cells after extreme loss [83], and after forced expression of Pdx1 [84]. It was later shown that Pdx1 maintains $\beta$-cell identity by repressing the $\alpha$-cell program [85]. Chera et al reported that the cell type transdifferentiating changes with age in RIP-DTR mice, whose $\beta$-cells bear DT receptors: after $>99 \%$ $\beta$-cell loss due to diphtheria toxin exposure in young animals, the $\beta$-cell compartment was reconstituted by transdifferentiation from $\delta$-cells; after puberty, the $\alpha$-cells were instead the regenerating cell type [86].

Islet environmental influences also impact heterogeneity and identity. Using proteomics, Mahmoud et al classified factors for the maintenance of $\beta$-cell stability and function during culture procedures, particularly in the interim between islet donor procurement and recipient transplant infusion [87]. Short and long-term in vitro conditions have been shown to induce a loss of mature islet-cell phenotype, including gene expression and GSIS metrics. The authors found that an extracellular protein, Apolipoprotein $E(A p o E)$, significantly increased the expression of key $\beta$-cell genes Ins2, Nkx2.2, Nkx6.1, Ucn3 and Glut2, which had been down-regulated after 4 weeks in low glucose [88]. Furthermore, Spijker et al demonstrated that dispersed human $\beta$-cells can undergo a conversion into glucagon-producing $\alpha$-cells which are indistinguishable from innate $\alpha$-cells [89]. These cells also retain their $\alpha$-cell phenotype after transplantation in vivo. This fate conversion occurs after $\beta$-cell degranulation, and is characterized by $\mathrm{Pdx} 1$ and $\mathrm{Nkx6.1}$ presence in glucagon ${ }^{+}$ cells. Interestingly, the transdifferentiation process can be blocked by lentiviral inhibition of Arx, further supporting the importance of this TF for $\alpha$-lineage specification [89].

While variable in their experimental methodologies, rationales, and results, the data shown here demonstrate substantial evidence supporting the existence and variability in $\beta$-cell heterogeneity, and how loss or gain of specific genes has substantial effect on cell function.

\section{Beta Cell Dedifferentiation as A Result of Hyperglycemia and Diabetes Mellitus}

Examples of $\beta$-cell dysfunction and consequent dedifferentiation caused by metabolic stress have emerged as a critically topical explanation for the epidemic of patients with T2DM; the most recent data available from 2017 shows that $9.7 \%$ of the US adult general population has diabetes, 91.2\% of those with T2DM [90]. This number does not include those with pre-diabetes, impaired fasting glucose, nor patients with metabolic syndrome, thus estimation of the global impact of impaired $\beta$-cell function is widely underestimated.

Many describe the islet stress process as metabolic exhaustion from chronic load, leading to severe $\beta$-cell dysfunction [91]. Multiple mechanisms have been attributed, including oxidative stress from glucose metabolism [92, 93], and endoplasmic reticulum (ER) strain, specifically the unfolded protein response (UPR), causing impaired insulin secretion [94-96]. Lu et al depicts $\beta$-cell loss of identity as the result of a two-hit hypothesis: sustained metabolic stress on the $\beta$-cell, and loss of polycomb-silencing via PRC2, triggering dedifferentiation of $\beta$-cells and consequent diabetes [97]. Polycomb comprises two repressive complexes, PRC1 and PRC2, which control gene silencing [98]. It is likely that a combination of many factors contribute to islet loss-of-function.

Alleviation of metabolic over-demand on the $\beta$-cell is an obvious first step. From the perspective of the islet, attempts to promote $\beta$-cell "rest" is not new, such as exogenous insulin supplementation, which turns off endogenous production [99]. New techniques now exist to 
achieve this metabolic stasis, including lowering the glucose set-point, improving insulin sensitivity following treatment with thiazolidinedione (TZD) therapy, glucagon-like-peptide-1 receptor (GLP$1 R$ ) agonism alone, and/or in combination with sodium/glucose cotransporter-2 inhibition (SGLT$2 \mathrm{i})$, which have proven effective in a mouse model of T2DM using $\beta$-cell-deficient obese hyperglycemic/hyperinsulinemic KS $d b / d b$ mice [100].

Beta-cell dedifferentiation and functional changes with insulin resistance (IR) in the absence of hyperglycemia have been documented, which illustrate the natural history of disease progression. Aguayo-Mazzucato reported that mouse $\beta$-cell aging markers have heterogeneous distribution and are induced by IR; indeed, these cells can be stratified by the relative presence of the insulin-like growth factor 1 receptor (IGF1R) and aging markers p16 ${ }^{\text {ink4a }}$, p53BP1, and senescence-associated $\beta$-galactosidase. Importantly, these aging markers increased after the introduction of insulin resistance or ER stress [101]. Fiori et al examined non-human primates fed a high-fat/high-sugar "westernized" diet (HFS) for 24 months, with and without the polyphenol resveratrol [102] (HFS+Resv), compared to a standard-diet (SD) group. Increased GSIS and IR were documented in both HFS and HFS+Resv diets compared with SD [103]. There were alterations in $\alpha$ - and $\beta$-cell proportions, and an increase in $\alpha$-cells containing glucagon and GLP-1 with HFS diet suggesting $\beta$ cell dedifferentiation, whereas HFS+Resv islets were morphologically similar to SD. And comparable to other studies recorded, HFS islets demonstrated a decrease in mature $\beta$-cell transcription factors including FoxO1, Nkx6.1, Nkx2.2, and $\mathrm{Pdx} 1$, which did not occur with resveratrol supplementation. Similar changes were observed in human islets in vitro, and suggest that the effects of resveratrol are mediated through Sirtuin 1 (Sirt1) [104, 105], as the islets showed a significantly decreased insulin secretion response when a Sirt1 inhibitor was applied [103]. Islet morphology was further shown to be altered in non-diabetic, insulin-resistant human islets relative to insulin-sensitive islets, demonstrating increased islet size and an elevated number of $\beta$ - and $\alpha$-cells that resulted in an altered $\beta$-cell to $\alpha$-cell area in the IR group [106].

As IR and impaired glycemia progress to overt diabetes, the loss of mature $\beta$ - and $\alpha$-cell phenotypes similarly manifest. Hyperglycemia was shown to reversibly alter islet structure and function, such that $\beta$-cell-specific expression of a human activating $\mathrm{K}_{\mathrm{ATP}}$ channel mutation in adult mice led to rapid diabetes and defined alterations in islet morphology, ultrastructure, and gene expression [107]. Sustained hyperglycemia was shown to be associated with a reduction in insulinpositive cells and an increase in glucagon-positive cells in islets, without alterations in cell turnover. Furthermore, some $\beta$-cells began expressing glucagon, whilst retaining many $\beta$-cell characteristics, representing identity loss. Hyperglycemia, rather than $\mathrm{K}_{\mathrm{ATP}}$ channel activation, underlies these changes, as they were prevented by insulin therapy and reversed by sulphonylureas [107]. Talchai and colleagues described $\beta$-cell dedifferentiation as a mechanism of $\beta$-cell failure in type 2 diabetes. Using a mouse model of FoxO1-deficient $\beta$-cells, the authors reported that FoxO1 ablation caused hyperglycemia with reduced $\beta$-cell mass following canonical drivers of metabolic stress, such as pregnancy and aging [108]. The loss of $\beta$-cell mass was shown to be the result of dedifferentiation and not $\beta$-cell death, challenging established paradigms [109]. Furthermore, these dedifferentiated $\beta$-cells reverted to progenitor-like phenotypes, expressing Ngn3, Oct4, Nanog, and L-Myc. A minority of FoxO1-deficient $\beta$-cells adopted the $\alpha$-cell phenotype, expressing glucagon. These data demonstrate that FoxO1 is required to maintain the $\beta$-cell fate under metabolic stress, and Pdx1, MafA, and Nkx6.1 alone are insufficient to maintain $\beta$-cell fate in the hyperglycemic metabolic environment [108]. Mis-expression of similar transcription factors 
present in islets from donors with T2DM has been further demonstrated, shown by altered MafA and Pax4 presence in $\alpha$-cells [110]. In another example from the Accili group, human $\beta$-cell dedifferentiation was scored using multiple indicators of endocrine lineage (hormones), markers of mature endocrine function (synaptophysin and chromogranin A), transcription factors, and an endocrine progenitor cell marker, aldehyde dehydrogenase 1A3 (ALDH1A3). Comparing pancreata from control non-diabetic (ND) vs. T2DM donors, dedifferentiated cells represented $31.9 \%$ of $\beta$ cells in T2DM vs. $8.7 \%$ in ND, and $16.8 \%$ vs. $6.5 \%$ of all endocrine cells. The number of ALDH1A3positive/hormone-negative cells was shown to be 3-fold higher in T2DM than ND controls. There was further evidence of $\beta$-cell specific transcription factors present in glucagon- and somatostatinexpressing cells of donor samples with diabetes [111]. In another study, Spijker et al demonstrated an 8-fold increase in bihormonal, insulin ${ }^{+}$glucagon ${ }^{+}$cell presence in T2DM vs. ND human islets (4.05\% vs $0.52 \%)$, affecting $33 \%$ of the islets in pancreata with T2DM vs. $13 \%$ in ND control donors [112]. These bihormonal cells demonstrated an exclusively non-nuclear MafA expression pattern, and FoxO1 exhibited disparity in compartment staining presence, being found primarily in the cytoplasm of ND-control islets, as compared to the nucleus of T2DM cells. Furthermore, nuclear $\mathrm{Pdx} 1$ was expressed in a subset of glucagon ${ }^{+} \mathrm{Nkx} 6.1^{+}$cells; overall, these results suggest diabetesdriven endocrine-cell dedifferentiation [112]. Furthermore, there was a correlation between the

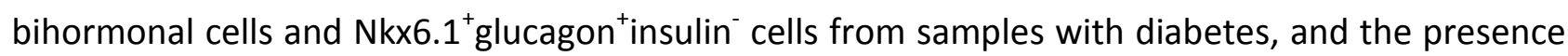
and extent of islet amyloidosis [112]. IAPP is produced by the $\beta$-cell and co-released with insulin in response to stimuli; IAPP is normally soluble in its monomeric state, but forms misfolded islet amyloid in type 2 diabetes [113]. Further evidence from Bader et al showed that the human Fltp ortholog Cfap126, as well as SLC2A2 and Pdx1, were significantly down-regulated in human islets from pre-diabetic donors, and further down-regulated in islets from T2DM donors compared to ND samples, suggesting that Wnt/PCP signaling and $\beta$-cell maturation and/or function are impaired by hyperglycemia and altered metabolic status [56]. The $\beta$-cell maturation marker Ucn 3 was further shown to be co-secreted with insulin upon glucose sensing, promoting somatostatin release from $\delta$-cells, ensuring appropriate responses to glucose fluctuation in a feedback loop with insulin and glucagon. Importantly, Ucn3 was shown to be depleted from $\beta$-cells in multiple examples of diabetes and sustained hyperglycemia, specifically in humans with T2DM [114]. Rescue of dedifferentiated Ucn3-negative $\beta$-cells was reported by the addition of a small molecule inhibitor of TGF $\beta$ receptor I, Alk5 inhibitor II. It was found to restore mature pancreatic $\beta$-cell identity after extended hyperglycemia and exposure to inflammatory cytokines, re-expressing Ucn3 and key $\beta$-cell transcription factors [115]. In yet another paper, Dahan et al showed that a subset of $\beta$ - and $\delta$ - cells in islets from donors with T2DM expressed the stomach hormone gastrin, which is otherwise expressed in the pancreas only during embryogenesis [116]. In vivo and in vitro data demonstrate that gastrin expression in the $\beta$-cell was eradicated after restitution of normoglycemia [116]. And, in recently diagnosed pancreas samples with T2DM, $\beta$-cells showed evidence of $\alpha$-cell colocalization, as well as the presence of the mesenchymal marker vimentin, indicating both $\beta$-cell dedifferentiation and reprogramming to other cell lineages [117]. The presence of vimentin in the endocrine cells of patients with T2DM has been similarly shown by others, demonstrating a higher expression in $\alpha$-cells than $\beta$-cells, and relative to ND-control donor samples [118]. These vimentin-positive $\beta$-cells were not apoptotic, and had reduced expression of Nkx6.1 and Pdx1. However, these dual-lineage cells were neither associated with islet amyloidosis, 
nor with bihormonal expression (insulin + glucagon) [118], contrary to other groups' findings described above [104, 107, 108, 113].

There is also emerging evidence for $\beta$-cell dedifferentiation in T1DM. Examination of remnant $\beta$-cells and isolated islets from T1DM donors illustrated retained insulin secretion regulation, although there was a reduction in MafA and Nkx2.2 gene expression; $\alpha$-cells however demonstrated loss of function, as well as variation in $\alpha$ - and $\beta$-cell lineage programs [119]. Implantation of islets into an immune-protected in vivo environment allowed for partial recovery of $\alpha$-cell phenotypic identity, but no change in $\beta$-cell function, suggesting that $\alpha$-cell dysregulation contributes to disease burden in addition to established $\beta$-cell loss [119]. Lam et al examined a large cohort of human pancreas samples (+/- T1DM) for assessment of $\beta$-cell mass, endocrine cell turnover by proliferation and apoptosis, and co-expression of insulin and glucagon. The authors demonstrated a minimal proportion of transdifferentiated or bihormonal cell presence; only $0.01 \%$

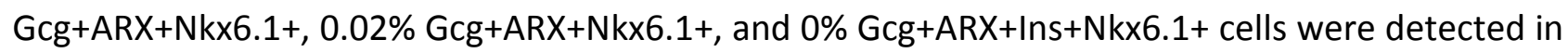
ND pancreata. T1DM pancreata, in comparison, did not contain any cells expressing all 4 of the $\alpha$ and $\beta$-cell markers tested. The authors thus concluded that there was no apparent, or measurable, transdifferentiation using these techniques [120]. However, these conditions may be too stringent, as multiple other groups have shown loss of the mature markers Arx and $\mathrm{Nkx6.1}$ in dedifferentiated cells, and Nkx6.1 is required for mature $\beta$-cell function, a state incongruent with dedifferentiation [121]. Interestingly however, a recent report from the same group demonstrated a highly proliferative population of cells present in adolescent and young adult donors with and without T1DM. These cells expressed Arx and cytoplasmic Sox9; furthermore, about 1/3 expressed glucagon, although the majority were hormone-negative [122]. These data suggest lineage plasticity within adolescent and adult human pancreata, and further implicate the role of the $\alpha$ cell. As T1DM is an autoimmune disease, one group identified a subset of immune-resistant $\beta$-cells in a mouse non-obese-diabetic (NOD) model. Rui and others suggestedthat this sub-population develops from normal $\beta$-cells after immune attack, and demonstrated reduced expression of genes associated with mature $\beta$-cell identity [123].The authors provide evidence for a cell survival program activation; alternatively this could be a consequence of dedifferentiation in response to autoimmunity.

\section{Endocrine Cell Dedifferentiation in the Transplantation Setting}

As evidenced above, islet phenotype can be altered by its environment. Due to inflammation and exocrine pancreas insufficiency consequent to chronic pancreatitis, extensive damage to the endocrine compartment can result in pancreatogenic or type 3c diabetes [124]. Similarly, cystic fibrosis-related diabetes (CFRD) is a common and severe complication of CF, which can consequently require islet allo-transplantation. Recently, Hart et al showed that $\sim 65 \%$ of $\beta$-cell area was lost in CF pancreata, evidenced by pancreatic remodeling, inflammation, and peri-islet adipocyte and fibrosis deposition, and not by inherent islet abnormalities in the cystic fibrosis transmembrane conductance regulator (CFTR) gene. The authors further found that the islet niche and islet morphology were altered in CF, which likely impacts insulin and glucagon secretion [125].

Chiefly in the transplant setting, cell identity maintenance is of critical importance. However, there is relative scarcity of data available. Anderson et al examined islet cell identity in two retrieved intraportal islet allotransplant grafts from deceased recipients who maintained excellent 
graft function and continuous insulin independence for 13 and 3 years. The authors describe a loss of Ucn3 presence as well as glucagon colocalization in insulin-expressing $\beta$-cells present; in contrast, no Ucn3-negative $\beta$-cells were seen in non-diabetic deceased donor control islets in pancreas sections [126]. The authors postulated this to be a dedifferentiation survival mechanism to counteract the stress caused by islet isolation, including ischemia and consequent changes to vasculature during engraftment [126]. While there is no way to assess the timing of the islet dedifferentiation retrospectively (i.e., pre - or post- transplant), and the small sample size studied precludes broad conclusions, these data suggest that loss of mature cell phenotype is a persistent issue warranting further investigation. In a separate report, the same patient sample whose transplant functioned for 13 years showed little-to-no amyloid deposition in the liver, suggesting retained function and low cytotoxic effects [127]. Islet amyloid has been shown to lead to progressive $\beta$-cell dysfunction and cell death, contributing to islet transplantation failure [113].

Mezza et al examined changes in islet morphology secondary to insulin resistance from pancreas samples obtained during 50\% pancreato-duodenectomy surgery, from non-diabetic subjects classified as insulin-resistant or insulin-sensitive. In addition to changes in insulin secretion and sensitivity assessments, and alterations in $\alpha$ - and $\beta$ - size and proportion, the authors found that $77.7 \%$ of patients who were insulin resistant before surgery subsequently developed type 2 diabetes thereafter [106].

Recently, we sought to investigate the identity of islets in chronic pancreatitis patients undergoing pancreatectomy and islet auto-transplantation (PIAT), and if long-term transplant success could be compared with $\beta$-cell functional phenotype status at the time of transplant. All patients were non-diabetic at the time of transplant, and all received equivalent numbers of islets $(\sim 5000 \mathrm{IE} / \mathrm{kg})$. Using histological markers of $\beta$-cell identity including hormones, vimentin, synaptophysin, Ucn3, and MafA, we found that $\beta$-cell dedifferentiation was evident in all patients undergoing PIAT, which paralleled disease severity, and could be stratified relative to ND control and T2DM control donor samples [128]. These findings were further supported by pre- and postsurgical metabolic function tests, $\mathrm{HbA}_{1 \mathrm{c}}$, and GSIS assessments with up to 4 years follow-up. Results indicated that pre-surgical insulin resistance was associated with loss of $\beta$-cell phenotype, and hence function, at the time of surgery, and might suggest a possible pre-surgical tool which can inform transplant success [128]. These data further indicate that islet cell quality and maturity is paramount for long-term glucose homeostasis following transplantation. Furthermore, disease duration and degree of damage may impact the quality of cells available for transplant. Thus, islet identity may be impacted before and after transplantation, and should be considered when making clinical decisions including donor selection criteria.

\section{Targeting the Reduction of Metabolic Stress: The Bone-Pancreas Connection}

Multiple questions arise from these data, such as (how) can we identify islet or $\beta$-cell heterogeneity with diagnostic testing in living humans; if so, can we apply a standard metric to a threshold value; and related, is there an optimal time for intervention? Furthermore, is there a way to maintain or promote a mature and functional $\beta$-cell identity and phenotype in the global rise of insulin resistance, metabolic syndrome, and type 2 diabetes?

Clinical strategies for reversal of damage caused by hyperglycemia, pancreatic disease, and metabolic syndrome will be of critical importance moving forward. One potential target is 
osteocalcin (OC), an osteoblast-derived hormone found to have global body effects. The link between bone health, energy metabolism, and glucose regulation has been known for some time [129-132], although the mechanism of action only now is being elucidated [133, 134]. Osteocalcindeficient mice are mildly hyperglycemic [132]; insulin receptors are present on osteoblasts, and insulin signaling here regulates body composition [135]; and the ligand for osteocalcin, the Gprotein coupled receptor-6a (GPRC6a), is found on multiple cell types, including $\beta$-cells, allowing the undercarboxylated form of osteocalcin (u-OC) [136] to bind in a bone-pancreas feed-forward loop [137]. This signaling axis was supported by the finding that global GPRC6a ${ }^{-/}$mice had both osteopenia and metabolic syndrome, with glucose intolerance and fatty liver [138]. Osteocalcin has been found to contribute to the regulation of glucose tolerance, and insulin secretion and sensitivity in experimental animals, and serum osteocalcin concentration was inversely associated with blood markers of metabolic syndrome [139]. Importantly, this showed that disease progress could be quantified by the relative presence of osteocalcin, which putatively could be used as a diagnostic tool. Osteocalcin was further shown to induce $\beta$-cell proliferation by binding to GPRC6a; inactivation of this receptor in $\beta$-cells caused a reduction of insulin production and glucose intolerance. Importantly, this regulation occurs during both development and in adulthood [140]. In mice with $\beta$-cell-specific GPRC6a deletion, there were reductions in pancreas weight, islet number, insulin content, and insulin gene expression. Both islet size and $\beta$-cell proliferation were reduced in Gprc6a $a^{\beta-c e l l-c k o}$ mice compared with control mice, and the knock-out animals exhibited altered glucose tolerance, yet normal insulin sensitivity [141]. Furthermore, isolated islets from the $\beta$-specific GPCR6a-deficient mice demonstrated reduced GSIS in response to osteocalcin. Thus, the authors provide evidence that GPRC6a is a receptor for OC, and present a direct role for GPRC6a in regulating $\beta$-cell functions, including mass and insulin secretion [141]. Osteocalcin treatment of islets was further shown to increase both Ins1 and Ins2 insulin genes as well as cyclin-dependent kinases and cyclin D1 and D2, promoting $\beta$-cell proliferation $[133,142]$.

Our laboratory has shown that osteocalcin protects against nonalcoholic steatohepatitis (NASH) in a diet-induced mouse model of metabolic syndrome, targeting inflammation and fibrosis in liver and white adipose tissue [143]. In this model using middle-aged $L d l r^{-/-}$mice fed a Western-style, high fat/ high cholesterol diet, uOC treatment furthermore protected against insulin resistance [143]. We subsequently undertook an investigation of osteocalcin on isolated human islets from 22 donors, and showed that UOC-supplementation in vitro increased multiple targets, including insulin content, the proportion of $\beta$-cells relative to $\alpha$-cells, islet-cell proliferation, and the expression of the sulphonylurea receptor Sur1 [144]. Sur1 is important for glucose homeostasis and insulin secretion [145]. After transplantation into Nod.scid mice for 1 month, human islet grafts supplemented with $4.5 \mathrm{ng} / \mathrm{ml}$ decarboxylated-OC demonstrated increased human insulin and C-peptide content, enhanced in vivo GSIS response, and decreased presence of cells bihormonal for insulin and glucagon relative to non-supplemented islets, suggesting that osteocalcin contributed to endocrine cell redifferentiation [144]. Ferron et al further demonstrated that intermittent injection of osteocalcin improved glucose metabolism in mice and mitigated T2DM [146].

Subsequent evaluation of in vivo osteocalcin levels in children recently diagnosed with both T1DM and T2DM demonstrated an inverse correlation between $\mathrm{HbA}_{1 \mathrm{c}}$ and serum concentrations of uncarboxylated osteocalcin, specifically that low $\mathrm{UOC}$ was found in patients with poor glycemic control shown by high $\mathrm{HbA}_{1 \mathrm{c}}$ [147]. This was not significantly related to age, sex, race/ethnicity, 
diabetes subtype, or body weight status, although the association between $\mathrm{uOC}$ and $\mathrm{HbA}_{1 \mathrm{c}}$ was more pronounced in children with T2DM than with T1DM, and in males than females. This observation supports the known effect of $O C$ on insulin secretion and sensitivity, which are both impaired in T2DM [147]. Alterations in uOC levels has been shown in multiple subsequent reports, including in chronic pancreatitis patients [148], in postmenopausal women with metabolic syndrome [149], and in a pediatric population with metabolic syndrome, insulin resistance and obesity [150]. Furthermore, there was lower bone turnover, and hence lower serum uOC, in Mexican American men, but not women, with T2DM who had poorer glycemic control [151]. Importantly, Sanchez-Enriquez et al demonstrated a link between cardiovascular risk factors for patients with T2DM, including high BMI, high fasting plasma glucose, and high HDL, and low serum levels of $\mathrm{UOC}$, suggesting that osteocalcin could have more physiological roles than previously expected [152]. In a different model, patients who underwent liver transplantation and subsequently became diabetic post-surgery demonstrated that total osteocalcin was, yet again, inversely associated with plasma glucose levels and insulin resistance [153].

The finding of an inverse correlation of $\mathrm{UOC}$ with glycemic control warrants further hypothesisdriven research, particularly with respect to endogenous vs. exogenous reliance of insulin, the confounding influence of exercise, and variability in both patients and islet donors. Rigorous examination of the mechanisms responsible for osteocalcin action are underway, as well as further elucidation of the relationship between bone and endocrine health as it relates to disease mitigation. While osteocalcin as a direct therapeutic agent has not yet been shown in human trials, these data suggest its potential future utility as hormonal replacement strategy for improving glycemia in patients with metabolic syndrome or T2DM, or indeed, for increasing islet mass or function for transplants. These data underscore the importance of $\beta$-cell mature function, identity, and lineage maintenance in relation to endocrine pathologies in the clinical setting, including transplantation procedures.

\section{Author Contributions}

Christine Beamish and Omaima Sabek each contributed to the conceptualization, writing, and editing of the review.

\section{Funding}

Funding was provided by the Vivian Smith Foundation.

\section{Competing Interests}

The authors have declared that no competing interests exist.

\section{References}

1. Shapiro A, Lakey J, Ryan E, Korbutt G, Toth E, Warnock G, et al. Islet transplantation in seven patients with type 1 diabetes mellitus using a glucocorticoid-free immunosuppressive regimen. N Engl J Med. 2000; 343: 230-238.

2. Shapiro AM, Pokrywczynska M, Ricordi C. Clinical pancreatic islet transplantation. Nat Rev Endocrinol. 2017; 13: 268-277. 
3. Thompson DM, Meloche M, Ao Z, Paty B, Keown P, Shapiro RJ, et al. Reduced progression of diabetic microvascular complications with islet cell transplantation compared with intensive medical therapy. Transplantation. 2011; 91: 373-378.

4. Noguchi H. Pancreatic islet transplantation. World J Gastrointest Surg. 2009; 1: 16-20.

5. Warnock GL, Thompson DM, Meloche RM, Shapiro RJ, Ao Z, Keown P, et al. A multi-year analysis of islet transplantation compared with intensive medical therapy on progression of complications in type 1 diabetes. Transplantation. 2008; 86: 1762-1766.

6. Thompson DM, Begg IS, Harris C, Ao Z, Fung MA, Meloche RM, et al. Reduced progression of diabetic retinopathy after islet cell transplantation compared with intensive medical therapy. Transplantation. 2008; 85: 1400-1405.

7. Hering BJ, Clarke WR, Bridges ND, Eggerman TL, Alejandro R, Bellin MD, et al. Phase 3 trial of transplantation of human islets in type 1 diabetes complicated by severe hypoglycemia. Diabetes Care. 2016; 39: 1230-1240.

8. Rafael E, Tibell A, Ryden M, Lundgren T, Savendahl L, Borgstrom B, et al. Intramuscular autotransplantation of pancreatic islets in a 7-year-old child: a 2-year follow-up. Am J Transplant. 2008; 8: 458-462.

9. O'Connell PJ, Holmes-Walker DJ, Goodman D, Hawthorne WJ, Loudovaris T, Gunton JE, et al. Multicenter Australian trial of islet transplantation: Improving accessibility and outcomes. Am J Transplant. 2013; 13: 1850-1858.

10. Sabek OM, Cowan P, Fraga DW, Gaber AO. The effect of isolation methods and the use of different enzymes on islet yield and in vivo function. Cell Transplant. 2008; 17: 785-792.

11. Sabek OM, Fraga DW, Henry J, Gaber LW, Kotb M, Gaber AO. Expression of transforming growth factor-beta by human islets: Impact on islet viability and function. Cell Transplant. 2007; 16: 775-785.

12. Benedini S, Ermetici F, Briganti S, Codella R, Terruzzi I, Maffi P, et al. Insulin-mimetic effects of short-term rapamycin in type 1 diabetic patients prior to islet transplantation. Acta Diabetol. 2018; 55: 715-722.

13. Hire K, Ngo D, Stewart-Maynard K, Hering B, Bansal-Pakala P. FoxP3+, and not CD25+, T cells increase post-transplant in islet allotransplant recipients following anti-CD25+ rATG immunotherapy. Cell Immunol. 2012; 274: 83-88.

14. Schuetz C, Markmann JF. Islet cell transplant: Update on current clinical trials. Curr Transplant Rep. 2016; 3: 254-263.

15. Choudhary P, Rickels MR, Senior PA, Vantyghem MC, Maffi P, Kay TW, et al. Evidenceinformed clinical practice recommendations for treatment of type 1 diabetes complicated by problematic hypoglycemia. Diabetes Care. 2015; 38: 1016-1029.

16. Puri $S$, Folias AE, Hebrok M. Plasticity and dedifferentiation within the pancreas: Development, homeostasis, and disease. Cell Stem Cell. 2015; 16: 18-31.

17. Okada TS. Transdifferentiation in animal cells: Fact or artifact?. Develop Growth and Differ. 1986; 28: 213-221.

18. Pan FC, Wright C. Pancreas organogenesis: From bud to plexus to gland. Dev Dyn. 2011; 240: 530-565.

19. Pagliuca FW, Melton DA. How to make a functional beta-cell. Development. 2013; 140: 24722483. 
20. Vegas AJ, Veiseh $\mathrm{O}$, Gurtler M, Millman JR, Pagliuca FW, Bader AR, et al. Long-term glycemic control using polymer-encapsulated human stem cell-derived beta cells in immunecompetent mice. Nat Med. 2016; 22: 306-311.

21. Bruin JE, Asadi A, Fox JK, Erener S, Rezania A, Kieffer TJ. Accelerated maturation of human stem cell-derived pancreatic progenitor cells into insulin-secreting cells in immunodeficient rats relative to mice. Stem Cell Rep. 2015; 5: 1081-1096.

22. Saber N, Bruin JE, O'Dwyer S, Schuster H, Rezania A, Kieffer TJ. Sex differences in maturation of human embryonic stem cell-derived beta cells in mice. Endocrinology. 2018; 159: 18271841.

23. Rezania A, Bruin JE, Riedel MJ, Mojibian M, Asadi A, Xu J, et al. Maturation of human embryonic stem cell-derived pancreatic progenitors into functional islets capable of treating pre-existing diabetes in mice. Diabetes. 2012; 61: 2016-2029.

24. Bruin JE, Rezania A, Xu J, Narayan K, Fox JK, O'Neil JJ, et al. Maturation and function of human embryonic stem cell-derived pancreatic progenitors in macroencapsulation devices following transplant into mice. Diabetologia. 2013; 56: 1987-1998.

25. Bruin JE, Erener S, Vela J, Hu X, Johnson JD, Kurata HT, et al. Characterization of polyhormonal insulin-producing cells derived in vitro from human embryonic stem cells. Stem Cell Res. 2014; 12: 194-208.

26. Pepper AR, Pawlick R, Bruni A, Wink J, Rafiei Y, O'Gorman D, et al. Transplantation of human pancreatic endoderm cells reverses diabetes post transplantation in a prevascularized subcutaneous site. Stem Cell Rep. 2017; 8: 1689-1700.

27. Pepper AR, Pawlick R, Gala-Lopez B, MacGillivary A, Mazzuca DM, White DJ, et al. Diabetes is reversed in a murine model by marginal mass syngeneic islet transplantation using a subcutaneous cell pouch device. Transplantation. 2015; 99: 2294-2300.

28. Pagliuca FW, Millman JR, Gurtler M, Segel M, Van Dervort A, Ryu JH, et al. Generation of functional human pancreatic beta cells in vitro. Cell. 2014; 159: 428-439.

29. van der Meulen T, Huising MO. Maturation of stem cell-derived beta-cells guided by the expression of urocortin 3. Rev Diabetic Stud: RDS. 2014; 11: 115-132.

30. Perl S, Kushner JA, Buchholz BA, Meeker AK, Stein GM, Hsieh M, et al. Significant human $\beta$ cell turnover is limited to the first three decades of life as determined by in vivo thymidine analog incorporation and radiocarbon dating. J Clin Endocrinol Metab. 2010; 95: E234-E239.

31. Teta $M$, Long $S$, Wartschow $L$, Rankin $M$, Kushner J. Very slow turnover of beta-cells in aged adult mice. Diabetes. 2005; 54: 2557-2567.

32. Mosser RE, Maulis MF, Moulle VS, Dunn JC, Carboneau BA, Arasi K, et al. High-fat dietinduced beta-cell proliferation occurs prior to insulin resistance in $\mathrm{C} 57 \mathrm{BI} / 6 \mathrm{~J}$ male mice. Am J Physiol Endocrinol Metab. 2015; 308: E573-E582.

33. Shirakawa J, Fernandez M, Takatani T, El Ouaamari A, Jungtrakoon $P$, Okawa ER, et al. Insulin signaling regulates the FoxM1/PLK1/CENP-A pathway to promote adaptive pancreatic beta cell proliferation. Cell Metab. 2017; 25: 868-882.e5.

34. Shirakawa J, Kulkarni RN. Novel factors modulating human beta-cell proliferation. Diabetes Obes Metab. 2016; 18: 71-77.

35. Seferovic M, Beamish C, Mosser R, Townsend S, Pappan K, Poitout V, et al. Increases in bioactive lipids accompany early metabolic changes associated with $\beta$-cell expansion in response to short-term high fat diet. Am J Physiol Endocrinol Metab. 2018; 315: E1251-E1263. 
36. Helman A, Avrahami D, Klochendler A, Glaser B, Kaestner KH, Ben-Porath I, et al. Effects of ageing and senescence on pancreatic beta-cell function. Diabetes Obes Metab. 2016; 18: 5862.

37. Meier JJ, Kohler CU, Alkhatib B, Sergi C, Junker T, Klein HH, et al. Beta-cell development and turnover during prenatal life in humans. Eur J Endocrinol. 2010; 162: 559-568.

38. Rankin MM, Kushner JA. Aging induces a distinct gene expression program in mouse islets. Islets. 2010; 2: 345-352.

39. Krishnamurthy J, Ramsey MR, Ligon KL, Torrice C, Koh A, Bonner-Weir S, et al. p16INK4a induces an age-dependent decline in islet regenerative potential. Nature. 2006; 443: 453-457.

40. Puri S, Roy N, Russ HA, Leonhardt L, French EK, Roy R, et al. Replication confers beta cell immaturity. Nat Commun. 2018; 9: 485.

41. El-Gohary Y, Tulachan S, Wiersch J, Guo P, Welsh C, Prasadan K, et al. A smad signaling network regulates islet cell proliferation. Diabetes. 2014; 63: 224-236.

42. Smukler SR, Arntfield ME, Razavi R, Bikopoulos G, Karpowicz P, Seaberg R, et al. The adult mouse and human pancreas contain rare multipotent stem cells that express insulin. Cell Stem Cell. 2011; 8: 281-293.

43. Beamish CA, Strutt BJ, Arany EJ, Hill DJ. Insulin-positive, Glut2-low cells present within mouse pancreas exhibit lineage plasticity and are enriched within extra-islet endocrine cell clusters. Islets. 2016; 8: 65-82.

44. Seaberg RM, Smukler SR, Kieffer TJ, Enikolopov G, Asghar Z, Wheeler MB, et al. Clonal identification of multipotent precursors from adult mouse pancreas that generate neural and pancreatic lineages. Nat Biotechnol. 2004; 22: 1115-1124.

45. Thorens B. GLUT2, glucose sensing and glucose homeostasis. Diabetologia. 2015; 58: 221-232.

46. Beamish CA, Mehta S, Strutt BJ, Chakrabarti S, Hara M, Hill DJ. Decrease in Ins+Glut2LO betacells with advancing age in mouse and human pancreas. J Endocrinol. 2017; 233: 229-241.

47. Razavi R, Najafabadi HS, Abdullah S, Smukler S, Arntfield M, van der Kooy D. Diabetes enhances the proliferation of adult pancreatic multipotent progenitor cells and biases their differentiation to more beta-cell production. Diabetes. 2015; 64: 1311-1323.

48. Beamish CA, Zhang L, Szlapinski SK, Strutt BJ, Hill DJ. An increase in immature beta-cells lacking Glut2 precedes the expansion of beta-cell mass in the pregnant mouse. PLoS One. 2017; 12: e0182256.

49. Rieck S, Kaestner $\mathrm{KH}$. Expansion of beta-cell mass in response to pregnancy. Trends Endocrinol Metab. 2010; 21: 151-158.

50. Szabat M, Luciani DS, Piret JM, Johnson JD. Maturation of adult beta-cells revealed using a $\mathrm{Pdx1}$ /insulin dual-reporter lentivirus. Endocrinology. 2009; 150: 1627-1635.

51. Liu H, Guz Y, Kedees MH, Winkler J, Teitelman G. Precursor cells in mouse islets generate new beta-cells in vivo during aging and after islet injury. Endocrinology. 2010; 151: 520-528.

52. Cox AR, Gottheil SK, Arany EJ, Hill DJ. The effects of low protein during gestation on mouse pancreatic development and beta cell regeneration. Pediatr Res. 2010; 68: 16-22.

53. van der Meulen T, Xie R, Kelly OG, Vale WW, Sander M, Huising MO. Urocortin 3 marks mature human primary and embryonic stem cell-derived pancreatic alpha and beta cells. PLoS One. 2012; 7: e52181. 
54. Blum B, Hrvatin S, Schuetz C, Bonal C, Rezania A, Melton DA. Functional beta-cell maturation is marked by an increased glucose threshold and by expression of urocortin 3. Nat Biotechnol. 2012; 30: 261-264.

55. van der Meulen T, Mawla AM, DiGruccio MR, Adams MW, Nies V, Dolleman S, et al. Virgin beta cells persist throughout life at a neogenic niche within pancreatic islets. Cell Metab. 2017; 25: 911-926.e6.

56. Bader E, Migliorini A, Gegg M, Moruzzi N, Gerdes J, Roscioni SS, et al. Identification of proliferative and mature beta-cells in the islets of Langerhans. Nature. 2016; 535: 430-434.

57. Roscioni SS, Migliorini A, Gegg M, Lickert H. Impact of islet architecture on beta-cell heterogeneity, plasticity and function. Nat Rev Endocrinol. 2016; 12: 695-709.

58. Johnston NR, Mitchell RK, Haythorne E, Pessoa MP, Semplici F, Ferrer J, et al. Beta cell hubs dictate pancreatic islet responses to glucose. Cell Metab. 2016; 24: 389-401.

59. Westacott MJ, Ludin NWF, Benninger RKP. Spatially organized beta-cell subpopulations control electrical dynamics across islets of langerhans. Biophys J. 2017; 113: 1093-1108.

60. Wang YJ, Golson ML, Schug J, Traum D, Liu C, Vivek K, et al. Single-cell mass cytometry analysis of the human endocrine pancreas. Cell Metab. 2016; 24: 616-626.

61. Dorrell C, Schug J, Canaday PS, Russ HA, Tarlow BD, Grompe MT, et al. Human islets contain four distinct subtypes of beta cells. Nat Commun. 2016; 7: 11756.

62. Wills QF, Boothe T, Asadi A, Ao Z, Warnock GL, Kieffer TJ, et al. Statistical approaches and software for clustering islet cell functional heterogeneity. Islets. 2016; 8: 48-56.

63. Gannon M, Kulkarni RN, Tse HM, Mauvais-Jarvis F. Sex differences underlying pancreatic islet biology and its dysfunction. Mol Metab. 2018; 15: 82-91.

64. Hall E, Volkov P, Dayeh T, Esguerra JLS, Salö S, Eliasson L, et al. Sex differences in the genomewide DNA methylation pattern and impact on gene expression, microRNA levels and insulin secretion in human pancreatic islets. Genome Biol. 2014; 15: 522-544.

65. Puri S, Akiyama H, Hebrok M. VHL-mediated disruption of Sox 9 activity compromises beta-cell identity and results in diabetes mellitus. Genes Dev. 2013; 27: 2563-2575.

66. Puri S, Garcia-Nunez A, Hebrok M, Cano DA. Elimination of von Hippel-Lindau function perturbs pancreas endocrine homeostasis in mice. PLoS One. 2013; 8: e72213.

67. Arnes L, Leclerc K, Friel JM, Hipkens SB, Magnuson MA, Sussel L. Generation of Nkx2.2:lacZ mice using recombination-mediated cassette exchange technology. Genesis. 2012; 50: 612624.

68. Sussel L, Kalamaras J, Hartigan-O'Connor D, Meneses J, Pedersen R, Rubenstein J, et al. Mice lacking the homeodomain transcription factor $\mathrm{Nkx2.2}$ have diabetes due to arrested differentiation of pancreatic $\beta$ cells. Development. 1998; 125: 2213-2221.

69. Papizan JB, Singer RA, Tschen SI, Dhawan S, Friel JM, Hipkens SB, et al. Nkx2.2 repressor complex regulates islet beta-cell specification and prevents beta-to-alpha-cell reprogramming. Genes Dev. 2011; 25: 2291-2305.

70. Gutierrez GD, Bender AS, Cirulli V, Mastracci TL, Kelly SM, Tsirigos A, et al. Pancreatic beta cell identity requires continual repression of non-beta cell programs. J Clin Invest. 2017; 127: 244259.

71. Collombat P, Mansouri A, Hecksher-Sorensen J, Serup P, Krull J, Gradwohl G, et al. Opposing actions of Arx and Pax4 in endocrine pancreas development. Genes Dev. 2003; 17: 2591-2603. 
72. Collombat P, Hecksher-Sorensen J, Krull J, Berger J, Riedel D, Herrera PL, et al. Embryonic endocrine pancreas and mature beta cells acquire alpha and PP cell phenotypes upon Arx misexpression. J Clin Invest. 2007; 117: 961-970.

73. Courtney M, Gjernes E, Druelle N, Ravaud C, Vieira A, Ben-Othman N, et al. The inactivation of Arx in pancreatic alpha-cells triggers their neogenesis and conversion into functional betalike cells. PLoS Genet. 2013; 9: e1003934.

74. Wilcox CL, Terry NA, Walp ER, Lee RA, May CL. Pancreatic alpha-cell specific deletion of mouse Arx leads to alpha-cell identity loss. PLoS One. 2013; 8: e66214.

75. Chakravarthy H, Gu X, Enge M, Dai X, Wang Y, Damond N, et al. Converting adult pancreatic islet alpha cells into beta cells by targeting both Dnmt1 and Arx. Cell Metab. 2017; 25: 622634.

76. Li J, Casteels $T$, Frogne $T$, Ingvorsen $C$, Honore $C$, Courtney $M$, et al. Artemisinins target GABAA receptor signaling and impair alpha cell identity. Cell. 2017; 168: 86-100.e15.

77. Ackermann AM, Moss NG, Kaestner KH. GABA and artesunate do not induce pancreatic alpha-to-beta cell transdifferentiation in vivo. Cell Metab. 2018; 28: 787-792.e3.

78. van der Meulen T, Lee S, Noordeloos E, Donaldson CJ, Adams MW, Noguchi GM, et al. Artemether does not turn alpha cells into beta cells. Cell Metab. 2018; 27: 218-225.e4.

79. Sosa-Pineda B, Chowdhury K, Torres M, Oliver G, Gruss P. The Pax4 gene is essential for differentiation of insulin-producing beta cells in the mammalian pancreas. Nature. 1997; 386: 399-402.

80. Collombat $P, X u X$, Ravassard P, Sosa-Pineda B, Dussaud S, Billestrup N, et al. The ectopic expression of Pax4 in the mouse pancreas converts progenitor cells into alpha and subsequently beta cells. Cell. 2009; 138: 449-462.

81. Al-Hasani K, Pfeifer A, Courtney M, Ben-Othman N, Gjernes E, Vieira A, et al. Adult duct-lining cells can reprogram into beta-like cells able to counter repeated cycles of toxin-induced diabetes. Dev Cell. 2013; 26: 86-100.

82. Mitchell RK, Nguyen-Tu MS, Chabosseau P, Callingham RM, Pullen TJ, Cheung R, et al. The transcription factor Pax6 is required for pancreatic beta cell identity, glucose-regulated ATP synthesis, and $\mathrm{Ca}(2+)$ dynamics in adult mice. J Biol Chem. 2017; 292: 8892-8906.

83. Thorel F, Nepote V, Avril I, Kohno K, Desgraz R, Chera S, et al. Conversion of adult pancreatic alpha-cells to beta-cells after extreme beta-cell loss. Nature. 2010; 464: 1149-1154.

84. Yang YP, Thorel F, Boyer DF, Herrera PL, Wright CV. Context-specific alpha- to-beta-cell reprogramming by forced Pdx1 expression. Genes Dev. 2011; 25: 1680-1685.

85. Gao T, McKenna B, Li C, Reichert M, Nguyen J, Singh T, et al. Pdx1 maintains beta cell identity and function by repressing an alpha cell program. Cell Metab. 2014; 19: 259-271.

86. Chera S, Baronnier D, Ghila L, Cigliola V, Jensen JN, Gu G, et al. Diabetes recovery by agedependent conversion of pancreatic delta-cells into insulin producers. Nature. 2014; 514: 503-507.

87. Kin T, Senior P, O'Gorman D, Richer B, Salam A, Shapiro AM. Risk factors for islet loss during culture prior to transplantation. Transplant Int. 2008; 21: 1029-1035.

88. Mahmoud Al, Galdos FX, Dinan KA, Jedrychowski MP, Davis JC, Vujic A, et al. Apolipoprotein E is a pancreatic extracellular factor that maintains mature beta-cell gene expression. PLoS One. 2018; 13: e0204595. 
89. Spijker H, Ravelli R, Mommaas-Kienhuis A, van Apeldoorn A, Engelse $M$, Zaldumbide A, et al. Conversion of mature human beta-cells into glucagon-producing alpha-cells. Diabetes. 2013; 62: 2471-2480.

90. Xu G, Liu B, Sun Y, Du Y, Snetselaar LG, Hu FB, et al. Prevalence of diagnosed type 1 and type 2 diabetes among US adults in 2016 and 2017: Population based study. BMJ. 2018; 362: k1497.

91. Swisa A, Glaser B, Dor Y. Metabolic stress and compromised identity of pancreatic beta cells. Front Genet. 2017; 8: 21.

92. Kaneto H, Kajimoto Y, Fujitani Y, Matsuoka T, Sakamoto K, Matsuhisa M, et al. Oxidative stress induces p21 expression in pancreatic islet cells: possible implication in beta-cell dysfunction. Diabetologia. 1999; 42: 1093-1097.

93. Kaneto $\mathrm{H}, \mathrm{Xu} \mathrm{G}$, Fujii N, Kim S, Bonner-Weir S, Weir GC. Involvement of c-Jun N-terminal kinase in oxidative stress-mediated suppression of insulin gene expression. J Biol Chem. 2002; 277: 30010-30018.

94. Izumi T, Yokota-Hashimoto H, Zhao S, Wang J, Halban PA, Takeuchi T. Dominant negative pathogenesis by mutant proinsulin in the Akita diabetic mouse. Diabetes. 2003; 52: 409-416.

95. Kaufman RJ. Stress signaling from the lumen of the endoplasmic reticulum: coordination of gene transcriptional and translational controls. Genes Dev. 1999; 13: 1211-1233.

96. Evans-Molina C, Hatanaka M, Mirmira RG. Lost in translation: endoplasmic reticulum stress and the decline of beta-cell health in diabetes mellitus. Diabetes Obes Metab. 2013; 15: 159169.

97. Lu TT, Heyne S, Dror E, Casas E, Leonhardt L, Boenke T, et al. The polycomb-dependent epigenome controls beta cell dysfunction, dedifferentiation, and diabetes. Cell Metab. 2018; 27: 1294-1308.e7.

98. Margueron R, Reinberg D. The Polycomb complex PRC2 and its mark in life. Nature. 2011; 469: 343-349.

99. Turner RC, McCarthy ST, Holman RR, E. H. Beta-cell function improved by supplementing basal insulin secretion in mild diabetes. Br Med J. 1976; 1: 1252-1254.

100. Boland B, Brown CJ, Boland M, Cann J, Sulikowski M, Hansen G, et al. Pancreatic $\beta$-cell rest replenishes insulin secretory capacity and attenuates diabetes in an extreme model of obese type 2 diabetes. Diabetes. 2019; 68: 131-140.

101. Aguayo-Mazzucato C, van Haaren M, Mruk M, Lee TB, Jr., Crawford C, Hollister-Lock J, et al. Beta cell aging markers have heterogeneous distribution and are induced by insulin resistance. Cell Metab. 2017; 25: 898-910.e5.

102.Szkudelska K, Szkudelski T. Resveratrol, obesity, and diabetes. Eur J Pharmacol. 2010; 635: 1-8.

103. Fiori JL, Shin Y-K, Kim W, Krzysik-Walker SM, González-Mariscal I, Carlson OD, et al. Resveratrol prevents beta-cell dedifferentiation in nonhuman primates given a high-fat/highsugar diet. Diabetes. 2013; 62: 3500-3513.

104. Hubbard BP, Sinclair DA. Small molecule SIRT1 activators for the treatment of aging and agerelated diseases. Trends Pharmacol Sci. 2014; 35: 146-154.

105. Wu L, Zhou L, Lu Y, Zhang J, Jian F, Liu Y, et al. Activation of SIRT1 protects pancreatic betacells against palmitate-induced dysfunction. Biochim Biophys Acta. 2012; 1822: 1815-1825.

106. Mezza T, Muscogiuri G, Sorice GP, Clemente G, Hu J, Pontecorvi A, et al. Insulin resistance alters islet morphology in nondiabetic humans. Diabetes. 2014; 63: 994-1007. 
107. Brereton MF, Iberl $M$, Shimomura K, Zhang $Q$, Adriaenssens $A E$, Proks $P$, et al. Reversible changes in pancreatic islet structure and function produced by elevated blood glucose. Nat Commun. 2014; 5: 4639.

108. Talchai C, Xuan S, Lin HV, Sussel L, Accili D. Pancreatic beta cell dedifferentiation as a mechanism of diabetic beta cell failure. Cell. 2012; 150: 1223-1234.

109. Butler PC, Meier JJ, Butler AE, Bhushan A. The replication of beta cells in normal physiology, in disease and for therapy. Nat Clin Pract Endocrinol Metab. 2007; 3: 758-768.

110. Bonnavion R, Jaafar R, Kerr-Conte J, Assade F, van Stralen E, Leteurtre E, et al. Both PAX4 and MAFA are expressed in a substantial proportion of normal human pancreatic alpha cells and deregulated in patients with type 2 diabetes. PLoS One. 2013; 8: e72194.

111. Cinti F, Bouchi R, Kim-Muller JY, Ohmura Y, Sandoval PR, Masini M, et al. Evidence of beta-cell dedifferentiation in human type 2 diabetes. J Clin Endocrinol Metab. 2016; 101: 1044-1054.

112. Spijker HS, Song H, Ellenbroek JH, Roefs MM, Engelse MA, Bos E, et al. Loss of beta-cell identity occurs in type 2 diabetes and is associated with islet amyloid deposits. Diabetes. 2015; 64: 2928-2938.

113. Cao P, Marek $P$, Noor $H$, Patsalo V, Tu LH, Wang $H$, et al. Islet amyloid: From fundamental biophysics to mechanisms of cytotoxicity. FEBS Lett. 2013; 587: 1106-1118.

114. van der Meulen T, Donaldson CJ, Caceres E, Hunter AE, Cowing-Zitron C, Pound LD, et al. Urocortin3 mediates somatostatin-dependent negative feedback control of insulin secretion. Nat Med. 2015; 21: 769-776.

115. Blum B, Roose AN, Barrandon O, Maehr R, Arvanites AC, Davidow LS, et al. Reversal of beta cell de-differentiation by a small molecule inhibitor of the TGFbeta pathway. Elife. 2014; 3: e02809.

116. Dahan T, Ziv O, Horwitz E, Zemmour H, Lavi J, Swisa A, et al. Pancreatic $\beta$-cells express the fetal islet hormone gastrin in rodent and human diabetes. Diabetes. 2017; 66: 426-436.

117. White MG, Marshall HL, Rigby R, Huang GC, Amer A, Booth $T$, et al. Expression of mesenchymal and alpha-cell phenotypic markers in islet beta-cells in recently diagnosed diabetes. Diabetes Care. 2013; 36: 3818-3820.

118. Roefs MM, Carlotti F, Jones K, Wills H, Hamilton A, Verschoor $M$, et al. Increased vimentin in human alpha- and beta-cells in type 2 diabetes. J Endocrinol. 2017; 233: 217-227.

119. Brissova M, Haliyur R, Saunders D, Shrestha S, Dai C, Blodgett DM, et al. Alpha cell function and gene expression are compromised in type 1 diabetes. Cell Rep. 2018; 22: 2667-2676.

120. Lam CJ, Jacobson DR, Rankin MM, Cox AR, Kushner JA. Beta cells persist in T1D pancreata without evidence of ongoing beta-cell turnover or neogenesis. J Clin Endocrinol Metab. 2017; 102: 2647-2659.

121. Taylor BL, Liu FF, Sander M. Nkx6.1 is essential for maintaining the functional state of pancreatic beta cells. Cell Rep. 2013; 4: 1262-1275.

122. Lam C, Cox A, Jacobson D, Rankin M, Kushner J. Highly proliferative $\alpha$-cell-related islet endocrine cells in human pancreata. Diabetes. 2018; 67: 674-686.

123. Rui J, Deng S, Arazi A, Perdigoto AL, Liu Z, Herold KC. Beta cells that resist immunological attack develop during progression of autoimmune diabetes in NOD mice. Cell Metab. 2017; 25: 727-738. 
124. Ewald N, Kaufmann C, Raspe A, Kloer HU, Bretzel RG, Hardt PD. Prevalence of diabetes mellitus secondary to pancreatic diseases (type 3c). Diabetes Metab Res Rev. 2012; 28: 338342.

125. Hart NJ, Aramandla R, Poffenberger G, Fayolle C, Thames AH, Bautista A, et al. Cystic fibrosisrelated diabetes is caused by islet loss and inflammation. JCI Insight. 2018; 3: e98240.

126. Anderson SJ, White MG, Armour SL, Maheshwari R, Tiniakos D, Muller YD, et al. Loss of enddifferentiated beta-cell phenotype following pancreatic islet transplantation. Am J Transplant. 2018; 18: 750-755.

127. Muller YD, Morel P, Berney T. Absence of amyloid deposition in human islets transplantation after 13 years insulin independence. Transplantation. 2015; 99: e31-e32.

128. Beamish CA, Gaber AO, Fraga DW, Afshar S, Hamilton DJ, Sabek OM. Variability in endocrine cell identity in patients with chronic pancreatitis undergoing islet auto-transplantation. Am J Transplant. 2018; doi.org/10.1111/ajt.15154.

129. Achemlal L, Tellal S, Rkiouak F, Nouijai A, Bezza A, Derouiche el M, et al. Bone metabolism in male patients with type 2 diabetes. Clin Rheumatol. 2005; 24: 493-496.

130. Bouillon R, Bex M, Van Herck E, Laureys J, Dooms. L., Lesaffre E, et al. Influence of age, sex, and insulin on osteoblast function: osteoblast dysfunction in diabetes mellitus. J Clin Endocrinol Metab. 1995; 80: 1194-1202.

131. Ducy P, Schinke T, Karsenty $G$. The osteoblast: A sophisticated fibroblast under central surveillance. Science. 2000; 289: 1501-1504.

132. Ducy P, Desbois C, Boyce B, Pinero G, Story B, Dunstan C, et al. Increased bone formation in osteocalcin-deficient mice. Nature. 1996; 382: 448-452.

133. Lee NK, Sowa H, Hinoi E, Ferron M, Ahn JD, Confavreux C, et al. Endocrine regulation of energy metabolism by the skeleton. Cell. 2007; 130: 456-469.

134. Ferron M, Wei J, Yoshizawa T, Del Fattore A, DePinho RA, Teti A, et al. Insulin signaling in osteoblasts integrates bone remodeling and energy metabolism. Cell. 2010; 142: 296-308.

135. Fulzele K, Riddle RC, DiGirolamo DJ, Cao X, Wan C, Chen D, et al. Insulin receptor signaling in osteoblasts regulates postnatal bone acquisition and body composition. Cell. 2010; 142: 309319.

136. Gower BA, Pollock NK, Casazza K, Clemens TL, Goree LL, Granger WM. Associations of total and undercarboxylated osteocalcin with peripheral and hepatic insulin sensitivity and betacell function in overweight adults. J Clin Endocrinol Metab. 2013; 98: E1173-E1180.

137. Pi M, Wu Y, Quarles LD. GPRC6A mediates responses to osteocalcin in beta-cells in vitro and pancreas in vivo. J Bone Miner Res. 2011; 26: 1680-1683.

138. Pi M, Chen L, Huang MZ, Zhu W, Ringhofer B, Luo J, et al. GPRC6A null mice exhibit osteopenia, feminization and metabolic syndrome. PLoS One. 2008; 3: e3858.

139. Pittas AG, Harris SS, Eliades M, Stark P, Dawson-Hughes B. Association between serum osteocalcin and markers of metabolic phenotype. J Clin Endocrinol Metab. 2009; 94: 827-832.

140. Wei J, Hanna T, Suda N, Karsenty G, Ducy P. Osteocalcin promotes beta-cell proliferation during development and adulthood through Gprc6a. Diabetes. 2014; 63: 1021-1031.

141. Pi M, Kapoor K, Ye R, Nishimoto SK, Smith JC, Baudry J, et al. Evidence for osteocalcin binding and activation of gprc6a in beta-cells. Endocrinology. 2016; 157: 1866-1880. 
142. Ferron M, Hinoi E, Karsenty G, Ducy P. Osteocalcin differentially regulates beta cell and adipocyte gene expression and affects the development of metabolic diseases in wild-type mice. Proc Natl Acad Sci U S A. 2008; 105: 5266-5270.

143. Gupte AA, Sabek OM, Fraga D, Minze LJ, Nishimoto SK, Liu JZ, et al. Osteocalcin protects against nonalcoholic steatohepatitis in a mouse model of metabolic syndrome. Endocrinology. 2014; 155: 4697-4705.

144. Sabek OM, Nishimoto SK, Fraga D, Tejpal N, Ricordi C, Gaber AO. Osteocalcin effect on human beta-cell mass and function. Endocrinology. 2015; 156: 3137-3146.

145. Aittoniemi J, Fotinou C, Craig TJ, de Wet H, Proks P, Ashcroft FM. SUR1: A unique ATP-binding cassette protein that functions as an ion channel regulator. Philos Trans R Soc Lond B Biol Sci. 2009; 364: 257-267.

146. Ferron M, McKee MD, Levine RL, Ducy P, Karsenty G. Intermittent injections of osteocalcin improve glucose metabolism and prevent type 2 diabetes in mice. Bone. 2012; 50: 568-575.

147. Redondo MJ, Shirkey BA, Fraga DW, Gaber AO, Sabek OM. Serum undercarboxylated osteocalcin correlates with hemoglobin $A 1 \mathrm{c}$ in children with recently diagnosed pediatric diabetes. Pediatr Diabetes. 2017; 18: 869-873.

148. Greer JB, Greer P, Sandhu BS, Alkaade S, Wilcox CM, Anderson MA, et al. Nutrition and inflammatory biomarkers in chronic pancreatitis patients. Nutr Clin Pract. 2018; doi.org/10.1002/ncp.10186.

149. Zanatta LCB, Boguszewski CL, Borba VZC, Moreira CA. Association between undercarboxylated osteocalcin, bone mineral density, and metabolic parameters in postmenopausal women. Arch Endocrinol Metab. 2018; 62: 446-451.

150. Reinehr T, Roth CL. Inflammation markers in type 2 diabetes and the metabolic syndrome in the pediatric population. Curr Diab Rep. 2018; 18: 131.

151. Rianon NJ, Smith SM, Lee M, Pervin H, Musgrave P, Watt GP, et al. Glycemic control and bone turnover in older mexican americans with type 2 diabetes. J Osteoporos. 2018; 2018: 7153021.

152. Sanchez-Enriquez S, Ballesteros-Gonzalez IT, Villafan-Bernal JR, Pascoe-Gonzalez S, RiveraLeon EA, Bastidas-Ramirez BE, et al. Serum levels of undercarboxylated osteocalcin are related to cardiovascular risk factors in patients with type 2 diabetes mellitus and healthy subjects. World J Diabetes. 2017; 8: 11-17.

153. Martínez-Díaz-Guerra G, Guadalix S, Aramendi M, Librizzi S, García E, Jiménez C, et al. Serum levels of osteocalcin and insulin resistance in patients with impaired glucose tolerance or new-onset diabetes mellitus after liver transplantation. Horm Metab Res. 2016; 48: 325-330. 


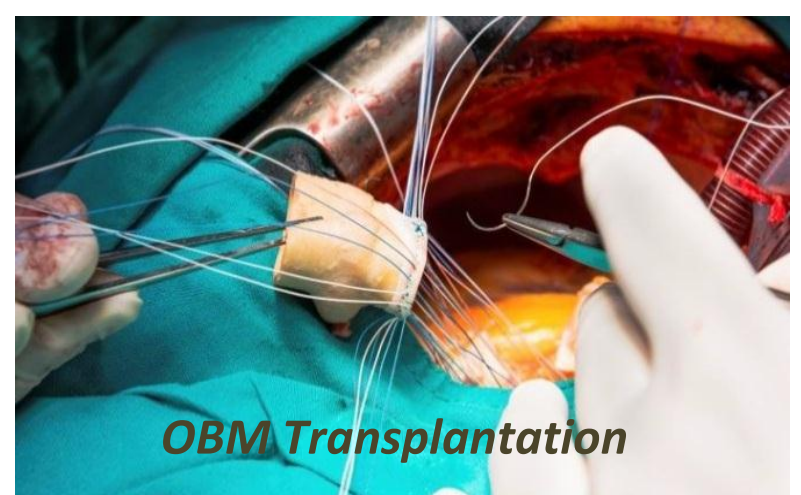

Enjoy OBM Transplantation by:

1. Submitting a manuscript

2. Joining in volunteer reviewer bank

3. Joining Editorial Board

4. Guest editing a special issue

For more details, please visit:

http://www.lidsen.com/journals/transplantation 